\title{
Analisa Kebutuhan Buku Ajar Bahasa Inggris SMK Jurusan Usaha Perjalanan Wisata
}

\author{
${ }^{1}$ Ririn Pratiwi Suharto, ${ }^{2}$ Istina Atul Makrifah, ${ }^{3}$ Widiarini \\ 1,2,3 Universitas Nahdlatul Ulama Blitar, Indonesia
}

Email: ${ }^{1}$ ririn_suharto@yahoo.co.id, ${ }^{2}$ Istina.atulmakrifah@gmail.com

33idiarini@unublitar.ac.id

\begin{tabular}{l}
$\overline{\text { Tersedia Online di }}$ \\
\hline http://www.jurnal.unublitar.ac.id/ \\
index.php/briliant
\end{tabular}

Sejarah Artikel

Diterima pada 24 Oktober 2019

Disetuji pada 11 Januari 2020

Dipublikasikan pada 29 Februari

2020 Hal. 19-26

\section{Kata Kunci:}

Analisa Kebutuhan; Buku Bahasa

Inggris; Jurusan Usaha Perjalanan

Wisata

\section{DOI}

http://dx.doi.org/10.28926/briliant. v4i4.376

\begin{abstract}
Abstrak: Penelitian ini bertujuan untuk mengalisa kebutuhan buku ajar Bahasa Inggris berdasarkan Project based Learning (PBL) untuk siswa Jurusan Usaha Perjalanan Wisata kelas X. Penelitian ini merupakan penelitian kualitatif yang menggunakan dua macam instrumen untuk pengumpulan data yaitu berupa kuesioner dan wawancara. Aspek yang dinilai dari penelitian ini adalah hasil tanggapan dari kebutuhan buku Bahasa Inggris yang sesuai dengan karakteristik siswa dan kurikulum dengan responden guru Bahasa Inggris dan siswa kelas X Jurusan Usaha Perjalanan Wisata. Hasil penelitian menunjukkan bahwa: (1) Buku Bahasa Inggris sesuai dengan KI dan KD, (2) Topik yang ada di dalam buku perlu lebih menarik dan sesuai dengan jurusan yang mengangkat pariwisata lokal, (3) Siswa dan guru Bahasa Inggris memerlukan buku Bahasa Inggris yang berhubungan dengan jurusan Usaha Perjalanan Wisata yang berbasis proyek untuk dapat belajar secara mandiri dan meningkatkan kemampuan berbahasa Inggris dengan praktek secara langsung.
\end{abstract}

\section{PENDAHULUAN}

Sektor industri pariwisata merupakan sektor yang saat ini sedang dikembangkan oleh pemerintah Indonesia maupun pihak lokal dengan mengangkat kearifan lokal suatu daerah. Sejalan dengan perkembangan pariwisata suatu daerah, maka akan menyerap sumber daya manusia sebagai pengelola maupun konsumen dari pariwisata itu sendiri. Jurusan Usaha Perjalanan Wisata merupakan suatu jurusan yang mempersiapkan peserta didik untuk mengelola suatu bisnis perjalanan wisata maupun mempersiapkan menjadi tenaga profesional yang dituntut untuk memiliki kemampuan yang berkualitas dalam bekerja. Salah satu kompetensi yang harus dimiliki yaitu berbahasa asing terutama bahasa inggris. Kemampuan berbahasa inggris sangat ditekankan untuk dikuasai oleh peserta didik karena ketika mereka terjun ke dunia pariwisata akan erat kaitannya dengan bahasa inggris terutama dalam mengelola pariwisata untuk skala internasional. Kemampuan bahasa inggris yang diperlukan meliputi kemampuan dalam berbicara atau lisan maupun secara tertulis. Sehingga, diharapkan lulusan jurusan Usaha Perjalanan Wisata mampu berdaya saing baik dalam skala nasional maupun internasional.

Penguasaan Bahasa Inggris di sekolah tidak hanya ditentukan dari metode pembelajaran, namun juga ditunjang oleh buku ajar yang baik dan sesuai dengan 
kebutuhan. Buku ajar merupakan salah satu sumber belajar siswa dalam proses pembelajaran. Buku ajar Bahasa Inggris yang tersedia di sekolah saat ini masih bersifat umum dimana materi yang ada di dalam buku memuat materi bahasa inggris yang dapat digunakan untuk SMA maupun SMK disemua jurusan. dalam persepsi selama ini, mempelajari bahasa inggris merupakan sebuah kebutuhan untuk mempersiapkan menghadapi Ujian Nasional. Sehingga banyak penekanan materi yang mengutamakan kemampuan menulis dan menganalisa suatu soal. Siswa di berikan metode drill dari guru dimana mereka hanya menerima materi pembelajaran. Hal ini membuat mereka kurang aktif dalam pengembangan kompetensi berbahasa inggris.

Buku ajar merupakan sebuah buku yang berisi lebih banyak melibatkan peserta didik untuk praktek (Tomlinson, 2011). Sehinggga, buku ajar tidak hanya sebagai sumber baca, melainkan sumber menggali pengetahuan dalam praktek. Biasanya buku dibuat agar peserta didik dapat menuliskan hasil kerjanya di buku tersebut dan sering terdapat kunci jawaban yang disediakan di bagian belakang buku untuk memberi umpan balik kepada peserta didik. Pengembangan buku ajar Bahasa Inggris untuk jurusan Usaha Perjalanan Wisata yang mampu menjadi sumber belajar peserta didik untuk belajar mandiri dan aktif dengan mengintegrasikan pengetahuan serta karya yang sesuai dengan bidang keahlian yang dipilih, merupakan salah satu alternatif yang dapat dilaksanakan untuk meningkatkan kemampuan berbahasa inggris peserta didik. Buku ajar bahasa inggris harus sesuai dengan standar kompetensi yang telah ditetapkan agar proses pembelajaran dapat berjalan dengan baik. Berdasarkan fakta tersebut, diperlukan analisis kebutuhan pada pengembangan buku ajar bahasa inggris untuk SMK jurusan Usaha Perjalanan Wisata kelas X yang sesuai dengan kebutuhan siswa, karakteristik materi dan kurikulum yang diterapkan. Johns (1991) mengatakan analisa kebutuhan merupakan langkah awal dalam desain pembelajaran dan menyediakan validitas dan relefansi untuk semua desain aktivitas pembelajaran. Langkah awal dalam melakukan analisa kebutuhan adalah menentukan tujuan sebenarnya dan tujuan seperti apa (Richards, 2002). Dimana salah satu tujuannya adalah untuk mengumpulkan informasi tentang masalah siswa dalam pengalamannya. Hal ini sejalan dengan pendapat (Tomlinson, 2011) menyatakan bahwa materi akan lebih mudah dipahami oleh peserta didik dimana pembelajaran berpusat pada keterkaitan dan kegunaan sesuai dengan kebutuhannya untuk mendapatkan bahasa. Sehingga materi yang sesuai dengan kebutuhan akan memudahkan siswa dalam memperoleh kemampuan bahasanya.

Zaini (2007: 57) dalam Nugroho, dkk. 2012 mengatakan bahwa pembelajaran aktif adalah sebuah kegiatan yang mengarahkan peserta didik untuk belajar secara aktif. Salah satu model pembelajaran yang mampu membuat peserta didik belajar aktif adalah Project based Learning. Menurut Hanafiah dan Suhana (2009: 30) Project based Learning merupakan model pembelajaran inovatif yang melibatkan peserta didik bekerja secara mandiri dalam pembelajaran dan menghasilkan produk nyata. Project based Learning merupakan cara belajar yang memberikan kebebasan kepada peserta didik dalam berfikir tentang bahan pengajaran dan tujuan yang direncanakan (Daryanto, 2009). Pembelajaran berbasis Proyek merupakan sebuah model pembelajaran yang menekankan aktivitas siswa dalam memecahkan masalah yang bersifat open-ended dan mengaplikasikan pengetahuan mereka dalam mengerjakan sebuah proyek untuk 
menghasilkan produk otentik tertentu (Abidin, 2007). Dalam Project based Learning atau pembelajaran berbasis proyek ini siswa dituntut aktif dalam mempelajari pengetahuan dan mengaplikasikannya dalam kerja nyata yang dirancang untuk menghasilkan produk. Peraturan Menteri Pendidikan dan Kebudayaan Republik Indonesia no. 65 tahun 2013 tentang standar proses pendidikan dasar dan menengah menyebutkan untuk mendorong kemampuan peserta didik untuk menghasilkan karya konstektual, baik individual maupun kelompok maka sangat disarankan menggunakan pendekatan pembelajaran yang menghasilkan karya berbasis pemecahan masalah (Project based Learning).

Sehubungan dengan hal tersebut di atas, maka peneliti melakukan analisis kebutuhan buku ajar Bahasa Inggris untuk Jurusan Usaha Perjalanan Wisata di kelas X. Menurut Hemalik (2012: 30-31) seseorang yang telah melakukan proses belajar akan menunjukkan adanya perubahan yang lebih baik. Buku ajar merupakan salah satu sumber belajar haruslah mampu menjadikan peserta didik memiliki perubahan baik dalam pengetahuan maupun keaktifan berperilaku. Dengan dilakukannya analisa kebutuhan (need analysis) pada pengembangan buku ajar diharapkan akan menghasilkan buku ajar yang membantu peserta didik dalam meningkatkan kompetensinya.

\section{METODE}

Metode penelitian ini adalah diskriptif kualitatif dimana data dijabarkan dengan pemaparan kata-kata. Data diperoleh dari hasil kuesioner dan wawancara dari guru dan siswa. Kuesioner diberikan kepada guru untuk mengetahui kebutuhan akan buku ajar karena guru merupakan praktisi di kelas. Kuesioner juga diberikan kepada siswa untuk mengetahui kebutuhan buku ajar karena mereka sebagai pengguna buku tersebut. Dilakukan pula analisis kurikulum untuk mengetahui kesesuaian buku Bahasa Inggris dengan kurikulum yang ada di sekolah terutama di jurusan Usaha Perjalanan Wisata kelas X. selain kuesioner, peneliti juga melakukan wawancara kepada guru dan siswa tentang persepsi mereka terhadap buku dan keefektifannya. Data yang diperoleh akan dipilah-pilah sesuai kebutuhan. Sehingga data yang tidak diperlukan akan dibuang. Selanjutnya, data yang diperoleh di kelas akan dianalisis untuk menghasilkan buku sesuai dengan kebutuhan dan karakteristik siswa. Penelitian ini dilakukan di SMK N 2 Blitar. sekolah dipilih didasari atas adanya jurusan Usaha Perjalanan Wisata di Kota dan Kabupaten Blitar.

\section{HASIL}

Analisis dilakukan menggunakan angket yang didistribusikan kepada guru Bahasa Inggris dan siswa. Tujuan dari analisis ini adalah menggali informasi dan tanggapan guru tentang buku ajar Bahasa Inggris yang digunakan di Jurusan Usaha Perjalanan Wisata kelas $\mathrm{X}$ dan kesesuaian kurikulum. Disamping tanggapan guru, tanggapan siswa mengenai buku ajar Bahasa Inggris juga diperlukan karena buku ajar ini dibuat untuk memenuhi kebutuhan siswa.

Berikut ini merupakan hasil angket yang diberikan kepada guru dan siswa: 
a. Hasil angket kebutuhan guru

\begin{tabular}{|c|c|c|c|c|c|c|}
\hline \multirow[t]{2}{*}{ No. } & \multirow[t]{2}{*}{ Pernyataan } & \multicolumn{5}{|c|}{ Hasil } \\
\hline & & SS & $\mathbf{S}$ & CS & KS & TS \\
\hline 1. & $\begin{array}{l}\text { Bahasa Inggris sangat penting untuk } \\
\text { mendukung kemampuan siswa sesuai } \\
\text { dengan jurusan (Usaha Perjalanan } \\
\text { Wisata) }\end{array}$ & $\sqrt{ }$ & & & & \\
\hline 2. & $\begin{array}{l}\text { Buku ajar Bahasa Inggris yang ada di } \\
\text { sekolah memudahkan guru dalam } \\
\text { meningkatkan kemampuan Bahasa } \\
\text { Inggris siswa secara lisan maupun } \\
\text { tulisan }\end{array}$ & & $\sqrt{ }$ & & & \\
\hline 3. & $\begin{array}{l}\text { Buku Bahasa Inggris yang digunakan } \\
\text { di sekolah menarik minat siswa untuk } \\
\text { menguasai Bahasa Inggris }\end{array}$ & & & & $\sqrt{ }$ & \\
\hline 4. & $\begin{array}{l}\text { Topic-topik yang ada di buku sudah } \\
\text { sesuai kurikulum yang ada di sekolah }\end{array}$ & & & & $\sqrt{ }$ & \\
\hline 5. & $\begin{array}{l}\text { Buku ajar Bahasa Inggris membuat } \\
\text { siswa aktif dalam menggali informasi }\end{array}$ & & & & $\sqrt{ }$ & \\
\hline 6. & $\begin{array}{l}\text { Buku Bahasa Inggris yang digunakan } \\
\text { di sekolah menggunakan bahasa yang } \\
\text { mudah dipahami }\end{array}$ & & $\sqrt{ }$ & & & \\
\hline 7. & $\begin{array}{l}\text { Terdapat gambar ilustrasi yang } \\
\text { memudahkan dalam pemahaman } \\
\text { objek }\end{array}$ & & & & $\sqrt{ }$ & \\
\hline 8. & $\begin{array}{l}\text { Instruksi dalam buku yang digunakan } \\
\text { di sekolah sudah jelas dan mudah } \\
\text { dipahami }\end{array}$ & & & $\sqrt{ }$ & & \\
\hline 9. & $\begin{array}{l}\text { Kegiatan eksplorasi perlu untuk } \\
\text { meningkatkan kemampuan Bahasa } \\
\text { Inggris siswa }\end{array}$ & $\sqrt{ }$ & & & & \\
\hline 10 . & $\begin{array}{l}\text { Perlunya menguasai Bahasa Inggris } \\
\text { dengan penerapan nyata di lapangan }\end{array}$ & $\sqrt{ }$ & & & & \\
\hline 11. & $\begin{array}{l}\text { Siswa tertarik dalam mengeksplor } \\
\text { pariwisata di Kabupaten dan Kota } \\
\text { Blitar }\end{array}$ & $\sqrt{ }$ & & & & \\
\hline 12. & $\begin{array}{l}\text { Buku Bahasa Inggris yang ada di } \\
\text { sekolah sudah relevan dengan } \\
\text { jurusan (Usaha Perjalanan Wisata) }\end{array}$ & & & & $\sqrt{ }$ & \\
\hline 13. & $\begin{array}{l}\text { Buku Bahasa Inggris yang ada di } \\
\text { sekolah membantu siswa dalam } \\
\text { penguasaan Bahasa Inggris baik lisan } \\
\text { mapupun tulisan }\end{array}$ & & & $\sqrt{ }$ & & \\
\hline 14. & $\begin{array}{l}\text { Buku ajar yang digunakan } \\
\text { memberikan contoh riil dan sesuai } \\
\text { dengan materi }\end{array}$ & & & & $\sqrt{ }$ & \\
\hline 15. & $\begin{array}{l}\text { Siswa membutuhkan materi } \\
\text { tambahan Bahasa Inggris untuk }\end{array}$ & $\sqrt{ }$ & & & & \\
\hline
\end{tabular}

22 BRILIANT: Jurnal Riset dan Konseptual

Volume 5 Nomor 1, Februari 2020 


\begin{tabular}{|l|l|l|l|l|l|l|}
\hline $\begin{array}{l}\text { jurusan (Usaha Perjalanan Wisata) } \\
\text { yang dapat dipakai secara } \\
\text { independen. }\end{array}$ & & & & & \\
\hline
\end{tabular}

Keterangan:

$\mathrm{SS}=$ Sangat Sesuai

$\mathrm{S}=$ Sesuai

$\mathrm{CS}=$ Cukup Sesuai

KS=Kurang Sesuai

TS=Tidak Sesuai

b. Hasil angket kesesuaian kurikulum

\begin{tabular}{|c|c|c|c|c|c|c|}
\hline \multirow[t]{2}{*}{ No. } & \multirow[t]{2}{*}{ Pernyataan } & \multicolumn{5}{|c|}{ Hasil } \\
\hline & & SS & $\mathbf{S}$ & $\mathbf{C S}$ & $\mathbf{K S}$ & TS \\
\hline 1. & Kesesuaian dengan SKL & & & & $\sqrt{ }$ & \\
\hline 2. & Kesesuaian dengan KD & & & $\sqrt{ }$ & & \\
\hline 3. & Kesesuaian indikator & & & & $\sqrt{ }$ & \\
\hline 4. & Kesesuaian tujuan pembelajaran & & & $\sqrt{ }$ & & \\
\hline 5. & $\begin{array}{l}\text { Kecukupan materi yang meliputi } \\
\text { konsep/materi dan alokasi waktu }\end{array}$ & & & $\sqrt{ }$ & & \\
\hline 6. & $\begin{array}{l}\text { Kedalaman materi ditinjau dari } \\
\text { karakteristik siswa }\end{array}$ & & & $\sqrt{ }$ & & \\
\hline 7. & Ketersediaan instruksi tugas & & & & $\sqrt{ }$ & \\
\hline 8. & $\begin{array}{l}\text { Buku sesuai dengan Kurikulum di } \\
\text { SMK Jurusan Usaha Perjalanan } \\
\text { Wisata }\end{array}$ & & & $\sqrt{ }$ & & \\
\hline
\end{tabular}

Keterangan:

$\mathrm{SS}=$ Sangat Sesuai

$\mathrm{S}=$ Sesuai

$\mathrm{CS}=$ Cukup Sesuai

KS=Kurang Sesuai

TS=Tidak Sesuai

c. Hasil angket kebutuhan siswa

Angket diberikan kepada 25 siswa kelas X Jurusan Usaha Perjalanan Wisata

\begin{tabular}{|c|l|c|c|}
\hline No. & \multicolumn{1}{|c|}{ Pernyataan } & \multicolumn{2}{|c|}{ Hasil } \\
\cline { 2 - 4 } 1. & $\begin{array}{l}\text { Yahasa Inggris sangat penting untuk } \\
\text { mendukung kemampuan siswa sesuai } \\
\text { dengan jurusan (Usaha Perjalanan } \\
\text { Wisata) }\end{array}$ & $100 \%$ & Tidak \\
\hline 2. & $\begin{array}{l}\text { Gemar membaca buku Bahasa Inggris } \\
\text { di luar kelas (di rumah) }\end{array}$ & $32 \%$ & $68 \%$ \\
\hline 3. & $\begin{array}{l}\text { Buku Bahasa Inggris yang digunakan } \\
\text { di sekolah menarik minat siswa untuk } \\
\text { menguasai Bahasa Inggris }\end{array}$ & $36 \%$ & $64 \%$ \\
\hline 4. & $\begin{array}{l}\text { Terdapat topik-topik yang menarik } \\
\text { di buku Bahasa Inggris }\end{array}$ & $32 \%$ & $68 \%$ \\
\hline
\end{tabular}




\begin{tabular}{|c|c|c|c|}
\hline 5. & $\begin{array}{l}\text { Buku ajar Bahasa Inggris membuat } \\
\text { siswa aktif dalam menggali informasi }\end{array}$ & $48 \%$ & $52 \%$ \\
\hline 6. & $\begin{array}{l}\text { Buku Bahasa Inggris yang digunakan } \\
\text { di sekolah menggunakan bahasa yang } \\
\text { mudah dipahami }\end{array}$ & $56 \%$ & $44 \%$ \\
\hline 7. & $\begin{array}{l}\text { Di dalam buku ajar Bahasa Inggris } \\
\text { terdapat gambar ilustrasi yang } \\
\text { memudahkan dalam pemahaman objek }\end{array}$ & $88 \%$ & $12 \%$ \\
\hline 8. & $\begin{array}{l}\text { Instruksi dalam buku yang digunakan } \\
\text { di sekolah sudah jelas dan mudah } \\
\text { dipahami }\end{array}$ & $48 \%$ & $52 \%$ \\
\hline 9. & $\begin{array}{l}\text { Kegiatan eksplorasi perlu untuk } \\
\text { meningkatkan kemampuan Bahasa } \\
\text { Inggris siswa }\end{array}$ & $84 \%$ & $16 \%$ \\
\hline 10. & $\begin{array}{l}\text { Perlunya menguasai Bahasa Inggris } \\
\text { dengan penerapan nyata di lapangan }\end{array}$ & $96 \%$ & $4 \%$ \\
\hline 11. & $\begin{array}{l}\text { Siswa tertarik dalam mengeksplor } \\
\text { pariwisata di Kabupaten dan Kota } \\
\text { Blitar }\end{array}$ & $100 \%$ & $0 \%$ \\
\hline 12. & $\begin{array}{l}\text { Buku Bahasa Inggris yang ada di } \\
\text { sekolah sudah relevan dengan jurusan } \\
\text { (Usaha Perjalanan Wisata) }\end{array}$ & $40 \%$ & $60 \%$ \\
\hline 13. & $\begin{array}{l}\text { Buku Bahasa Inggris yang ada di } \\
\text { sekolah membantu siswa dalam } \\
\text { penguasaan Bahasa Inggris baik lisan } \\
\text { maupun tulisan }\end{array}$ & $52 \%$ & $48 \%$ \\
\hline 14. & $\begin{array}{l}\text { Buku ajar yang digunakan } \\
\text { memberikan contoh riil dan sesuai } \\
\text { dengan materi }\end{array}$ & $60 \%$ & $40 \%$ \\
\hline 15. & $\begin{array}{l}\text { Siswa membutuhkan materi tambahan } \\
\text { Bahasa Inggris untuk jurusan (Usaha } \\
\text { Perjalanan Wisata) yang dapat dipakai } \\
\text { secara independen. }\end{array}$ & $96 \%$ & $4 \%$ \\
\hline
\end{tabular}

\section{PEMBAHASAN}

Berdasarkan hasil analisis angket yang diberikan kepada guru tentang buku ajar Bahasa Inggris yang digunakan di sekolah menunjukkan beberapa hal meliputi: (a) buku perlu sesuai dengan KD dan indicator, (b) buku yang mampu membuat siswa aktif dalam menggunakan Bahasa Inggris secara lisan dan tulisan, (c) buku yang memiliki ilustrasi yang memudahkan dalam pemahaman objek, (d) buku yang memiliki instruksi jelas dengan melibatkan siswa dalam aktif menggali ilmu, (e) buku yang membuat siswa aktif dalam mengeksplor pariwisata local di Kota dan Kabupaten Blitar, (f) buku yang dapat dipakai siswa secara independen.

Hasil angket kesesuaian kurikulum dengan buku menunjukkan bahwa (a) buku Bahasa Inggris yang digunakan belum sesuai dengan SKL karena bersifat umum untuk semua jurusan baik SMA/ SMK, (b) Di dalam buku ajar yang ada sudah dituliskan Kompetensi Dasar pada setiap materi, (c) Kesesuaian isi dengan kompetensi dasar dan indikator tidak terlihat karena dalam buku ini hanya 
mencantumkan kompetensi dasarnya saja, tetapi tidak ada indikatornya sehingga tidak spesifik pada sub kemampuan akhir yang diharapkan, (d) Materi sudah cukup lengkap tetapi dalam skala global sedangkan untuk materi buku ajar bahasa inggris yang sesuai dengan jurusan usaha perjalanan wisata tidak spesifik. Sehingga perlu pengembangan kurikulum untuk buku ajar yang sesuai dengan jurusan, (e) Instruksi tugas yang diberikan mencangkup pertanyaan berdasarkan bacaan dan action seperti bermain game yang langsung dilakukan di kelas. Pada buku ini tidak terdapat instruksi untuk project siswa membuat suatu produk untuk mengembangkan bahasa inggris mereka sesuai dengan jurusan usaha perjalanan wisata.

Menurut Prastowo (2013: 168) buku teks pelajaran berisi ilmu pengetahuan yang substansinya diturunkan dari kompetensi dasar yang tertuang dalam kurikulum untuk digunakan oleh siswa dalam belajar. Dari pendapat ini, kesesuaian kurikulum dengan buku ajar yang digunakan sangat penting karena pengembangan buku ajar didasari dari isi kurikulum yang telah ditetapkan. Pada analisis buku ajar yang dilakukan sudah memuat beberapa KD, namun perlu pengembangan materi sesuai dengan KD yang terdapat dalam silabus. Terutama dalam KD yang memuat tentang materi pariwisata yang terdapat dalam satu bab.

Berdasarkan hasil angket yang diberikan kepada 25 siswa didapatkan hasil sebagai berikut: (a) topic-topik yang tersaji di dalam buku kurang menarik siswa untuk mempelajari Bahasa Inggris, (b) instruksi yang ada di dalam buku kurang jelas dan sulit dipahami, (c) siswa menyukai kegiatan lapangan yang melibatkan siswa aktif dalam menggali informasi dan menggunakan Bahasa Inggris secara aktif, (d) siswa membutuhkan buku ajar Bahasa Inggris yang sesuai dengan jurusan Usaha Perjalanan Wisata.

Selain menggunakan angket, peneliti juga melakukan wawancara tidak terstruktur kepada guru Bahasa Inggris dan beberapa siswa. Hasil wawancara kepada guru menunjukkan buku ajar yang digunakan masih bersifat umum atau luas yang dapat digunakan oleh siswa untuk semua jurusan karena buku berasal dari Pemerintah. Buku Bahasa Inggris yang sesuai dengan kompetensi siswa di jurusan Usaha Perjalanan Wisata belum ada sehingga siswa menggunakan bahasa inggris banyak untuk kegiatan praktik menulis sedangkan praktek berbicara kurang. Wawancara yang dilakukan kepada beberapa siswa tentang pelaksanaan pembelajaran Bahasa Inggris menggunakan buku yang ada menunjukkan bahwa mereka kurang dapat menguasai penggunaan bahasa inggris secara aktif dalam percakapan karena tugas yang dikerjakan di buku lebih merujuk pada tugas tulis.

Penelitian yang dilakukan oleh Cahyati (2017) menunjukkan analisa kebutuhan buku ajar SMK yang difokuskan pada Jurusan Teknik Komputer Jaringan pada kesesuaian muatan materi dengan silabus kelas X semester 1. Hasil penelitian menunjukkan buku ajar Bahasa Inggris kurang sesuai dalam layout, keaslian ilustrasi dan kurang lengkap materi seperti soal-soal. Berbeda dengan penelitian tersebut, peneliti lebih terfokus pada menganalisa kebutuhan buku ajar Bahasa Inggris untuk jurusan Usaha Perjalan Wisata yang mana lulusannya merupakan sumber daya manusia pada bidang wisata yang lebih dituntut menggunakan bahasa inggris secara aktif. Analisa yang dilakukan meliputi analisa kesesuaian kurikulum, kebutuhan siswa tentang buku ajar Bahasa Inggris sesuai kompetensi lulusan, serta kedalaman materi buku ajar. Dari hasil analisa didapatkan bahwa buku ajar Bahasa Inggris yang dipakai di sekolah belum secara 
khusus dapat dipakai untuk Jurusan Usaha Perjalanan Wisata yang memuat kearifan lokal daerah.

\section{KESIMPULAN}

Analisis kebutuhan buku ajar Bahasa Inggris di kelas $\mathrm{X}$ jurusan Usaha Perjalanan Wisata diperlukan untuk menghasilkan sebuah buku yang dapat menjadi sumber belajar siswa. Buku ajar yang diharapkan memuat materi yang menarik dan membuat siswa lebih aktif dalam mengeksplor kemampuan sehingga dapat meningkatkan kompetensi Bahasa Inggrisnya untuk menghasilkan lulusan yang professional. Hasil analisis menunjukkan bahwa mereka sangat membutuhkan buku yang dapat membuat mereka aktif dalam mengeksplor kemampuan berbahasa inggris dan materi dalam buku yang menarik sehingga mudah dipahami.

\section{SARAN}

Dengan hasil analisis yang telah didapatkan, sangat perlu pengembangan buku ajar Bahasa Inggris yang sesuai dengan jurusan Usaha Perjalanan wisata yang sesuai dengan kurikulum dan kompetensi siswa. Sehingga diharapkan peneliti mengembangkan buku ajar untuk SMK sesuai dengan jurusan agar menunnjang kompetensi siswa

\section{DAFTAR RUJUKAN}

Hanafiah, Nanang dan Cucu Suhana. 2009. Konsep Strategi Pembelajaran. Bandung: Refika Aditama.

Daryanto. 2009. Panduan Proses Pembelajaran Inovatif. Jakarta: Publisher.

Abidin, Zainal. 2007. Analisis Eksistensial. Jakarta: Raja Grafindo.

Peraturan Menteri Pendidikan Nasional No. 65 Tahun 2016 tentang Standar Proses untuk Satuan Pendidikan Dasar dan Menengah. Jakarta: Depdiknas.

Nugroho, Sugeng, Suparmi dan Sarwanto. 2012. Pembelajaran IPA denga Metode Inquiry Terbimbing menggunakan Laboratorium Riil dan Vituil ditinjau dari Kemampuan Memorial dan Gaya Belajar Siswa. JURNAL INKUIRI ISSN: 2252-7893, Vol 1, No 3, 2012.

Tomlinson, Brian. 2011. Materials Development in Language Teaching. Cambridge University UK: Press

Prastowo, Andi. 2013. Panduan Kreatif Membuat Bahan Ajar Inovatif, Yogyakarta: DIVA Press.

Hemalik, Oemar. 2012. Proses Belajar Mengajar. Jakarta: Bumi Aksara.

Richards, J.C. 2002. Curriculum Development in Language Teaching. USA. Cambridge.

Cahyati, Sri Supiah \& Siska Rizkiani. 2017. Analisis Kebutuhan Siswa dalam Materi Buku Teks Bahasa Inggris Tingkat SMK. Jurnal Ilmiah UPT P2M STKIP Siliwangi, 5(1): 39-51. 